\section{PERILAKU BERBAGI PENGETAHUAN ANTAR PELAKU WIRAUSAHA DI RUANG KERJA BERSAMA}

\author{
Gita Widya Laksmini Soerjoatmodjo \\ Program Studi Psikologi \\ Universitas Pembangunan Jaya \\ gita.soerjoatmodjo@upj.ac.id
}

\begin{abstract}
Abstrak
Seiring dengan perkembangan zaman, perilaku bekerja (work behavior) mengalami perubahan sehingga memunculkan apa yang dikenal sebagai cara-cara kerja baru (new ways of working), termasuk di kalangan pelaku wirausaha (entrepreneurs).

Salah satu fenomena baru terkait dengan hal ini adalah tumbuhnya ruang kerja bersama (co-working space) yang mendorong perilaku berbagi pengetahuan (knowledge sharing), salah satu elemen penting dalam pengelolaan pengetahuan (knowledge management). Tulisan ini bertujuan menyintesiskan teori-teori tentang perilaku berbagi pengetahuan pada pelaku wirausaha di ruang kerja bersama.

Kata kunci: kewirausahaan, ruang kerja bersama, perilaku berbagi pengetahuan.
\end{abstract}

\section{Abstract}

Work behavior has undergone numerous changes over the years, leading to the development of new ways of working, especially amongst entrepreneurs.

One new related phenomenon is the emergence of co-working spaces that facilitate knowledge sharing, one of the key elements in knowledge management. This writing aims to synthesize existing theories on knowledge sharing amongst entrepreneurs in co-working space.

Keywords: entrepreneurship, co-working space, knowledge sharing behavior

\section{PENDAHULUAN}

\subsection{Latar Belakang}

Latar belakang tulisan ini adalah bahwa perilaku bekerja (work behavior) mengalami banyak perubahan. Lazimnya karyawan bekerja di kantor dari pukul 9 pagi sampai pukul 5 sore selama 5 hari seminggu. Kini makin banyak alternatif perilaku bekerja yang dikembangkan, antara lain bekerja jarak jauh (teleworking atau remote working), bekerja dengan jam kerja yang fleksibel (flexi-time) dan lain sebagainya. Semua ini termasuk dalam cara-cara kerja baru (new ways of working).

Cara-cara kerja baru ini sendiri didefinisikan oleh Jupp (2000) sebagai upaya untuk mengkaji ulang makna dari pekerjaan itu sendiri serta mengoptimalkan praktikpraktik bekerja. Korunka dan Gerdenitsch 
(2014) melihat cara-cara kerja baru ini sebagai bentuk fleksibilitas dalam bekerja secara temporal atau waktu serta spasial atau ruang - yang kini dimungkinkan berkata kemajuan teknologi.

Duffy (2000) lebih jauh meninjau bahwa cara-cara kerja baru ini mendorong lahirnya perspektif baru dalam memandang relasi antara waktu kerja dengan waktu senggang, relasi antara rumah dan kantor, termasuk di dalamnya relasi keseimbangan antara waktu untuk bekerja dan waktu untuk kegiatankegiatan lain, atau yang lazimnya disebut sebagai work-life balance.

Berdasarkan pada pandangan-pandangan di atas, maka dapat disimpulkan bahwa dalam mempertimbangkan cara-cara terbaik dalam bekerja, faktor hitung-hitungan biaya bisnis tidak lagi menjadi satu-satunya penentu. Terdapat hal-hal lain seperti kesejahteraan manusia, teknologi, komunitas dan lingkungan yang juga penting untuk dipertimbangkan.

Salah satu fenomena yang belakangan muncul terkait dengan cara-cara kerja baru ini adalah ruang kerja bersama (co-working space). Apakah yang dimaksud dengan ruang kerja bersama? Van Meel dan Brinkø (2014) menjelaskan bahwa pada pertengahan 1990-an, ahli pemrograman komputer Brad Neuberg keluar dari sebuah perusahaan besar karena memilih bekerja sebagai wirausaha. Sekalipun merasa terbebas dari dunia korporasi, ia merasa kehilangan struktur kerja ala kantor dan keberadaan rekan kerja. Hal inilah yang mendorong dirinya menciptakan apa yang kemudian dikenal sebagai ruang kerja bersama. Ia membentuk komunitas kerja bersama Spiral Muse di San Fransisco yang terdiri dari meja dapur, beberapa sofa serta beberapa meja kerja - yang ia sewakan dengan biaya bulanan.

Orsi dan Doskow (2009) menyamakan ruang kerja bersama seperti klub kebugaran, seseorang bisa datang kapan saja untuk bekerja, bekerja dalam durasi waktu yang ia inginkan, asalkan membayar sewa bulanan. Nilai tambah (added value) dari ruang kerja bersama ini adalah biaya yang lebih murah dibandingkan menyewa satu kantor utuh. Ruang kerja bersama menjadi alternatif tempat kerja dibandingkan ruang-ruang publik seperti kafe yang cenderung gaduh dengan fasilitas colokan listrik dan sinyal wi-fi Internet yang serba terbatas. Ruang kerja bersama ini pun membuat seseorang tidak lagi terisolir bekerja sendiri rumah tanpa keberadaan rekan kerja sehingga rentan mengalami penurunan motivasi kerja. Tak heran apabila ruang kerja bersama menjadi alternatif yang dipilih oleh para pelaku wirausaha.

Lebih jauh lagi, Muhrbeck, Waller dan Berglund (2011) memandang ruang kerja 
bersama sebagai komunitas tempat saling belajar dan bertukar pengetahuan demi membangun kolaborasi yang nantinya menggulirkan inovasi. Hal inilah yang dibayangkan oleh Brad Neuberg saat dirinya menginisiasi ruang kerja bersama untuk pertama kalinya di San Fransisco, dimana dirinya berangan-angan menciptakan satu komunitas dimana anggota-anggotanya tak sekedar berbagi ruang kerja dan fasilitas, tetapi juga makan siang bersama, melewatkan waktu senggang serta berpartisipasi dalam pengembangan komunitas.

Rumpun ilmu psikologi industri dan organisasi mengenal apa yang disebut sebagai pengelolaan pengetahuan (knowledge management), yang merupakan perluasan dari pengelolaan sumber daya manusia dan pengembangan organisasi. Pengetahuan adalah sesuatu yang dipandang bernilai. Tak heran ada adagium yang menyatakan bahwa pengetahuan adalah kekuasaan (knowledge is power).

Menurut Wang dan Noe (2010), pengetahuan adalah informasi yang sudah terlebih dahulu diproses oleh individu yang mencakup gagasan, fakta, kepakaran (expertise) serta penilaian (judgement) yang penting bagi kemajuan organisasi. Dalam manajemen pengetahuan, berbagi pengetahuan (knowledge sharing) merupakan hal yang penting. Mengapa?
Srivasta, Bartol dan Lock (2006) melihat bahwa berbagi pengetahuan merupakan kunci karena memungkinkan dilakukannya kodifikasi dan repositori dari pengetahuan yang ada, sehingga pengetahuan tersebut dapat dikembangkan seiring dengan perjalanan waktu. Agar pengetahuan dapat dikembangkan menjadi keunggulan kompetitif (competitive advantage), maka pengetahuan tersebut harus dibagi kepada orang-orang lain agar dapat diapropriasi dan ditingkatkan.

Literatur tentang manajemen pengetahuan mengakui bahwa berbagi pengetahuan bukan hal yang mudah mengingat adanya kecenderungan untuk menimbun pengetahuan (hoarding) demi kepentingan pribadi. Bock dan Kim (2002) mengutip survei yang dilakukan pada tahun 1997 oleh Ernst \& Young Center for Business Innovation pada 431 organisasi di Amerika Serikat dan Eropa. Survei tersebut menyebutkan bahwa salah satu kesulitan terbesar dari manajemen pengetahuan adalah mengubah perilaku berbagi pengetahuan.

\subsection{Rumusan Masalah}

Rumusan masalah dalam tulisan ini adalah bagaimana ruang kerja bersama dapat berkontribusi pada pemahaman tentang perilaku berbagi pengetahuan? Tulisan ini secara spesifik mengaitkan telaah ini pada 
para pelaku wirausaha yang menjadi penerima manfaat utama dari ruang kerja bersama.Dengan melihat perilaku berbagi pengetahuan pada para pelaku wirausaha yang menerima manfaat dari ruang kerja bersama, diharapkan tulisan ini dapat melahirkan pemahaman baru yang nantinya dapat berkontribusi pada bidang kewirausahaan, manajemen pengetahuan, cara-cara kerja baru dan psikologi industri dan organisasi.

\subsection{Tujuan Penulisan/Penelitian}

Tujuan tulisan ini adalah mensintesiskan teori-teori yang ada tentang kewirausahaan, ruang kerja bersama dan perilaku berbagi pengetahuan. Tulisan ini disusun dalam organisasi sebagai berikut: latar belakang yang menjelaskan gambaran umum, uraian teori tentang wirausaha dan pelaku wirausaha, tentang perilaku berbagi pengetahuan dan akhirnya tentang ruang kerja bersama, termasuk sejumlah contoh ruang kerja bersama yang ada di Indonesia. Tulisan ini kemudian dilanjutkan dengan kesimpulan yang dibangun atas sintesa dari teori-teori yang ada. Tulisan ini ditutup dengan diskusi yang menguraikan pengembangan-pengembangan teori di masa mendatang.

\section{TINJAUAN TEORITIS}

\subsection{Kewirausahaan}

Eisenmann (2013) mengutip Harvard Business School yang merumuskan kewirausahaan (entrepreneurship) sebagai upaya mengejar peluang yang melampaui sumber daya yang tersedia di bawah kendali seseorang. Lalu apakah yang dimaksud dengan pelaku wirausaha (entrepreneurs)? Nelson (2012) menjelaskan bahwa pelaku wirausaha adalah seseorang yang mengorganisir dan mengelola usaha dalam bentuk apapun, terutama bisnis, yang melibatkan pengambilan inisiatif dan resiko.

Perkembangan sektor wirausaha kemudian memunculkan berbagai tipologi pelaku wirausaha, antara lain pelaku wirausaha sosial (social entrepreneurs), pelaku wirausaha kreatif (creative entrepreneurs), pelaku wirausaha yang berbasis pada teknologi (technopreneurs) sampai intrapreneurs yaitu para karyawan perusahaan yang berorientasi pada optimasi peluang dan pengambilan inisiatif di dalam ruang lingkup internal organisasi.

Sektor wirausaha ini juga melahirkan bentuk-bentuk kewirausahaan, termasuk di dalamnya kewirausahaan kolaboratif (collaborative entrepreneurship). Quince (2011) menjelaskan bahwa kewirausahaan kolaboratif adalah relasi bisnis dimana keberhasilan suatu bisnis ditentukan oleh hubungan antar pribadi. Lebih lanjut lagi, Quince (2011) menjelaskan bahwa 
keberhasilan dari kewirausahaan kolaboratif ini ditentukan oleh sejumlah aspek antara lain tujuan yang sama (mutual goals), rasa saling menghormati (mutual respect) dan rasa saling percaya (mutual trust). Licht dan Siegel (2006) menjelaskan bahwa para perilaku wirausaha yang memilih bentuk kewirausahaan kolaboratif mencurahkan waktu, tenaga dan energi mereka untuk membangun investasi pada modal sosial demi nantinya menikmati hasil finansial di kemudian hari.

Kewirausahaan kolaboratif semacam ini dibangun melalui berbagai bentuk perilaku, antara lain perilaku berbagi pengetahuan (knowledge sharing). Paulin dan Suneson (2012) menjelaskan bahwa dalam berbagi pengetahuan, hal yang menjadi fokus adalah pengembangan modal sosial yang tumbuh dari interaksi antar individu. Perilaku berbagi pengetahuan sendiri diuraikan lebih lanjut pada bagian berikut ini.

\subsection{Berbagi Pengetahuan}

Perilaku berbagi pengetahuan (knowledge sharing) adalah pertukaran pengetahuan antara dua atau lebih individu, dimana salah satu pihak mengkomunikasikan pengetahuan yang ia miliki dan pihak lain mengasimilasi pengetahuan tersebut sehingga secara bersama-sama terciptalah pengetahuan baru (Paulin dan Suneson, 2012; Van den Hoff dan de Ridder, 2004).
Van den Hoff dan de Ridder (2004) lebih jauh menjelaskan bahwa perilaku berbagi pengetahuan terdiri dari dua proses kunci: pertama, mendonasikan pengetahuan (knowledge donating) yang dimiliki individu satu kepada individu lain; dan kedua mengkoleksi pengetahuan (knowledge collecting) yang dilakukan individu penerima informasi atas modal intelektual tersebut. Kedua proses sama-sama aktif tetapi bersifat berbeda serta dipengaruhi juga oleh faktor-faktor yang berbeda, misalnya teknologi, motivasi, iklim organisasi dan iklim komunikasi.

Semakin banyak pengetahuan yang dikoleksi oleh seseorang, maka semakin besar kesediaan orang tersebut untuk mendonasikan pengetahuannya kepada orang lain. Oleh karenanya perilaku mengkoleksi pengetahuan berpengaruh pada perilaku mendonasikan pengetahuan. Kesediaan seseorang berbagi pengetahuan adalah akibat dari keberhasilannya mengkoleksi pengetahuan.

Van den Hoff dan de Ridder (2004) menjelaskan bahwa individu lebih bersedia berbagi pengetahuan apabila mereka yakin bahwa pengetahuan tersebut bermanfaat dan lingkungan sekitar mengapresiasi serta menggunakan pengetahuan tersebut. Wang dan Noe (2010) juga mendukung pendapat tersebut dengan menyatakan bahwa perilaku 
berbagi pengetahuan dipengaruhi oleh tingkat keyakinan seseorang akan manfaat pengetahuan tersebut bagi orang lain.

Cabrera dan Cabrera (2005) menyebutkan bahwa perilaku berbagi pengetahuan ini dipengaruhi oleh beberapa hal, antara lain ikatan sosial dan pola serta frekuensi interaksi antar individu, penggunaan bahasa yang sama (a shared language) yang menyatukan individu satu dengan lainnya, rasa percaya antar pribadi, adanya norma yang mendukun perilaku untuk saling berbagi, adanya identifikasi bersama antar individu sebagai satu kelompok (group identification), adanya persepsi akan ganjaran atau reward, kemampuan diri (selfefficacy) dan harapan akan terjadinya perilaku resiprokal (expectation of reciprocity).

Lebih jauh lagi, Riege (2003) menjelaskan bahwa perilaku berbagi pengetahuan dipengaruhi oleh motivasi internal yakni rasa yakin seseorang bahwa pengetahuan yang dibagi memberikan manfaat bagi orang lain. Hal ini dilihat sebagai pendorong yang lebih kuat dibandingkan motivasi ekstrinsik misalnya harapan akan adanya imbalan dalam bentuk uang atau penilaian positif. Bock dan Kim (2002) melihat bahwa individu yang akin bahwa hubungannya dengan orang lain dapat menjadi semakin luas dan dalam melalui perilaku berbagi pengetahuan mempunyai sikap positif dalam berbagi pengetahuan. Sebaiknya keengganan dievaluasi orang lain (evaluation apprehension) atau rasa cemas karena takut mendapatkan evaluasi negatif dari orang lain merupakan hal yang menghambat perilaku berbagi pengetahuan.

Kajian literatur di atas menjelaskan bagimana sektor wirausaha, khususnya kewirausahaan kolaboratif, dapat memetik manfaat dari perilaku berbagi pengetahuan. Ruang kerja bersama diyakini dapat memfasilitasi perilaku berbagi pengetahuan tersebut. Adapun kajian literatur tentang ruang kerja bersama akan diuraikan pada bagian berikut ini.

\subsection{Ruang Kerja Bersama}

Ruang kerja bersama, sebagaimana telah dijelaskan pada bagian Latar Belakang, berangkat dari gagasan tentang komunitas kolaboratif. Forlano (2013) menjelaskan bahwa ruang kerja bersama dapat dimaknai sebagai apa yang dikenal dalam sosiologi arsitektur sebagai 'ruang ketiga' ('the third space'). Forlano (2013) menjelaskan lebih lanjut tentang 'ruang ketiga' sebagaimana dikonseptualisasikan oleh sosiolog Ray Oldernurg pada tahun 1989. Ruang ini adalah ruang bukan rumah dan bukan juga kantor, dimana batas atau sekat antar ruang pribadi dan ruang kerja seseorang tak lagi jelas. Perspektif ini meyakini bahwa 'ruang 
ketiga' seperti ini punya kontribusi penting pada pertumbuhan masyaraat sipil, demokrasi, pelibatan masarakat dan pembentukan makna atas tempat (sense of place).

Para penggiat ruang kerja bersama memandang ruang ini sebagai sebuah 'gerakan' yang bertumpu pada nilai-nilai kolaborasi, keterbukaan, komunitas dan keberlanjutan, yang bersandar pada gagasan ekonomi berbagi (shared economy) dimana memiliki akses (access) dipandang lebih penting dibandingkan kepemilikan (ownership).

Ruang kerja bersama ini dipandang oleh Van Meel dan Brinkø (2014) sebagai oase untuk kaum kreatif urban (urban creatives). Guzman dan Tang (2011) melihat bahwa sektor-sektor yang mendapat manfaat dari ruang kerja bersama adalah sektor desain grafis, jurnalisme, tenologi informasi, organisasi nirlaba atau sosial maupun kelompok profesi independen lainnya, termasuk pelaku wirausaha.

Guzman dan Tang (2011) mengutip survei majalah Deskmag yang mengungkapkan bahwa sejak bekerja di ruang kerja bersama, para pelaku wirausaha menjadi lebih sering bekerja dalam tim, lebih mudah mencapai keseimbangan antara waktu kerja dengan waktu senggang, mengalami peningkatan peluang dan kesempatan kerja sampai memperluas jejaring. Survei tersebut menyebutkan bahwa 42 persen respondennya mengaku mengalami kenaikan pendapatan (income).

Bercermin pada hal tersebut di atas, maka tidaklah mengherankan apabila ruang kerja bersama menjadi seperti jamur yang tumbuh subur di musim penghujan. Frost (2008) dalam tulisannya di The New York Times menyebutkan bahwa ada puluhan ruang kerja bersama bermunculan di Amerika Serikat dan di berbagai belahan dunia. Guzman dan Tang (2011) melihat bahwa sejak tahun 2005, ruang kerja bersama bermunculan di lebih dari 50 negara. Hal ini mereka amati dari direktori ruang kerja bersama yaitu Deskwanted. Direktori tersebut mendata bahwa ada 820 ruang kerja bersama di seluruh dunia terhitung per bulan Mei 2011. Johns dan Gratton (2013) memperbaharui catatan tersebut dengan menyebutkan bahwa pada tahun 2013, terdapat lebih dari 2.000 ruang kerja bersama di seantero jagad. Angka terbaru disodorkan oleh Van Meel dan Brinkø (2014). Mereka menyebutkan bahwa ada lebih dari 2.500 ruang kerja bersama di seluruh dunia, dimana kota-kota besar seperti London, New York dan Berlin memiliki lebih dari 60 ruang kerja bersama.

Bagi para pengguna ruang kerja bersama, salah satu daya tarik dari ruang alternatif ini 
adalah perbedaannya dengan dunia korporasi. Jones, Sundsted dan Bacigalupo (2009) menyebutkan bahwa berbeda dengan dunia korporasi, nilai-nilai yang berlaku di ruang kerja bersama adalah menetapkan sendiri jam kerja yang diinginkan dan berapa lama seseorang ingin bekerja, menentukan sendiri cara bekerja yang nyaman serta memilih proyek yang bermakna bagi perkembangan profesinoal maupun pertumbuhan pribadi.

Selain itu, nilai-nilai yang juga berlaku adalah penghayatan bahwa pekerjaan maupun kehidupan sosial sama-sama bernilai penting dan saling berjalin berkelindan. Selain itu, ruang kerja bersama dibangun di atas keyakinan bahwa interaksi dengan orang lain membantu memberikan energi, berkolaborasi, memecahkan masalah dan baik untuk kesejahteraan paripurna sosial (social well-being) (Jones, Sundsted dan Bacigalupo, 2009).

Di sisi lain, dunia korporasi juga menyambut baik kehadiran ruang kerja bersama. Ruang kerja bersama kini dianggap sebagai pintu masuk bagi korporasi untuk mengakses bakat-bakat baru. Oleh karenanya tak heran apabila Twitter, AT\&T dan Google mensponsori ruang kerja bersama demi menjaring pekerja maupun proyek inovatif (Van Meel dan Brinkø, 2014).

Kajian literatur di atas mengungkapkan bahwa ruang kerja bersama memfasilitasi perilaku berbagi pengetahuan yang merupakan dasar dari kewirausahaan kolaboratif. Hal ini selaras dengan pendapat Guzman dan Tang (2011) yang memandang bahwa ruang kerja bersama memfasilitasi inovasi dan inspirasi berkat terciptanya peluang dan penemuan yang lahir akibat perjumpaan antar individu yang datang dari berbagai bidang maupun spesialisasi yang berbeda.

\section{ANALISIS}

Ruang kerja bersama pertama di Indonesia adalah Comma Coworking Space yang berlokasi di bilangan Wolter Monginsidi Jakarta. Menurut Mardian (2013), Comma merupakan singkatan dari 'Collaboration Matters' dan berdiri sejak 1 Desember 2012. Comma merupakan satu dari 14 ruang kerja bersama di Indonesia yang disebut dalam TechInAsia (2013) yang tersebar di Bandung, Depok, Jakarta, Yogyakarta dan Bali. 


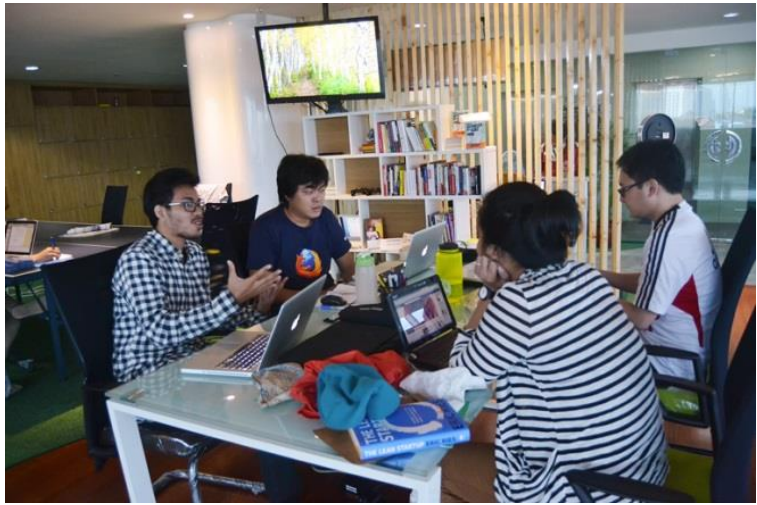

No Gambar:1

Sumber: Ruang Kerja Bersama Comma (The Jakarta Globe, 2013)

Ruang kerja bersama ini berbasis pada semangat komunitas, sebagaimana dapat dilihat pada kesepakatan keanggotaan (membership agreement) yaitu

"coworking adalah bekerja berdampingan bersama orang lain secara sukarela dengan kepercayaan mutual; itulah sebabnya kami ingin memastikan hak semua orang dalam komunitas ini terjaga dengan baik dan komunitas yang positif dan suportif terbentuk."

Lebih jauh lagi, kesepakatan keanggotaan Comma menguraikan sejumlah nukilan dari gambaran perilaku yang diharapkan muncul dari para pengguna ruang kerja bersama ini sebagaimana dirangkum dalam Tabel 1 berikut ini:

\section{Perilaku}

Berkelakuan baik, perlakukan orang lain seperti yang kamu harapkan orang lain lakukan untukmu atau, jika ada perbedaan pendapat, dengarkan dan sesuaikan perilakumu seandainya mereka menegurmu. Jika tidak, kamu diminta untuk memperbaiki sikap dalam 30 hari, dan kalau tidak dilakukan, keanggotaanmu akan dicabut. Kami sadar kalau ini terdengar cukup kejam, tapi kami harus menjaga komunitas tetap kondusif

Percaya pada dirimu sendiri, orang lain, dan semangat coworking. Dan, tunjukkan itu. Turut serta dalam membangun semangat positif, produktifitas, dan suasana yang menyenangkan di Comma. Bersikaplah suportif pada Comma dan sesama member agar kita semua bisa lebih sukses.

Kerja keras, bergembira, dan aktif berpartisipasi. Hal utama yang membuat Comma lebih dari sekedar tempat kerja adalah komunitas didalamnya. Seandainya kamu belum menyadarinya, KAMU adalah komunitas tersebut. Kamu memiliki kekuatan untuk membuat komunitas ini menjadi luar biasa. Jadi, gunakanlah.

Jadilah orang yang ramah dalam
bersosialisasi dan juga ramah lingkungan - paling tidak di Comma. Daur ulang. Jangan boros dengan sumber daya. Artinya, jangan biarkan air terus mengalir, matikan lampu jika tidak dibutuhkan, print di kedua 
sisi, dan hal baik lainnya - yang sudah sangat sering kita dengar sepanjang hidup kita.

No Tabel: 1

Sumber: Comma (2015)

Dapat dilihat pada uraian di atas bahwa ruang kerja bersama, salah satunya Comma sebagai contoh ruang kerja pertama di Indonesia, secara eksplisit menyebutkan gambaran perilaku yang berkontribusi pada tindakan berbagi pengetahuan di antara para pengguna ruang kerja bersama, terutama para pelaku wirausaha. Posisi ruang kerja bersama sebagai sebuah komunitas menjadikan ruang kerja bersama sebagai wadah untuk saling berbagi pengetahuan, yang pada akhirnya memberikan sumbangan pada pertumbuhan kewirausahaan kolaboratif.

Selain menyediakan ruang dan fasilitas, Comma juga menyelenggarakan sejumlah kegiatan. Sebagai contoh, pada saat tulisan ini disusun, situs Comma mengumumkan adanya tiga kegiatan yang diselenggarakan dengan berbagai mitra. Mitra-mitra tersebut berbagi pengetahuan dalam bentuk diskusi (talk show) bebas biaya yang dapat dihadiri oleh umum. Hal ini pun memiliki kontribusi pada perilaku berbagi pengetahuan yang ditumbuhsuburkan dalam ruang lingkup ruang kerja bersama.

\section{KESIMPULAN}

Kesimpulan dari tulisan di atas yang berupaya melakuan sintesa atas teori-teori yang ada adalah sebagi berikut.

Kewirausahaan kolaboratif didukung oleh adanya perilaku berbagi pengetahuan antar para pelaku wirausaha. Perilaku berbagi pengetahuan ini difasilitasi dalam ruang kerja bersama. Hal ini karena ruang kerja bersama berfungsi sebagai akselerator dari perilaku berbagi pengetahuan.

Perilaku berbagi pengetahuan ini merupakan dasar dari munculnya inovasi yang lahir dari kolaborasi, terutama melalui interaksi dari sektor dan kompetensi yang berbeda akan tetapi saling melengkapi. Pada akhirnya perkembangan dunia kewirausahaan dapat dipicu dari berbagai arah, termasuk di dalamnya pengembangan perilaku berbagi pengetahuan.

Psikologi, khususnya psikologi industri dan organisasi, diharapkan dapat berperan serta dalam pengembangan hal-hal tersebut di atas.

Terdapat berbagai peluang pengembangan tulisan ini ke dalam berbagai penelitian. Penelitian-penelitian tersebut antara lain adalah potret gambaran perilaku berbagi pengetahuan yang terjadi di ruang kerja bersama. Potret ini akan berguna demi pengembangan perilaku berbagi pengetahuan, yang merupakan elemen 
penting dalam isu pengelolaan pengetahuan. Hal ini dapat dilakukan dengan melakukan penelitian di berbagai ruang kerja bersama yang ada di berbagai kota di Indonesia untuk mendapatkan benang merah.

Penelitian lainnya adalah perbandingan antara perilaku berbagi di ruang kerja bersama dengan tempat kerja konvensional seperti ruang kantor. Penelitian ini dapat juga nantinya dapat melihat perbandingan perilaku antar karyawan dengan pelaku wirausaha.

Penelitian lanjutan yang juga dapat dikaji adalah identifikasi faktor-faktor yang berkontribusi pada perilaku berbagi pengetahuan di dalam lingkup ruang kerja bersama. Contoh faktor yang menarik untuk dikaji lebih lanjut adalah peran tuan rumah (host) pada ruang kerja bersama, pengaruh pengaturan meja kerja (table arrangement) dalam interior ruang kerja bersama, termasuk adanya ruang-ruang bersama yang bersifat pendukung antara lain meja makan atau pantry. Faktor-faktor yang juga menarik untuk diidentifikasi lebih lanjut adalah kegiatan-kegiatan yang dapat mendorong perilaku berbagi informasi, antara lain kegiatan makan bersama.

Selain itu, menarik juga untuk melakukan penelitian untuk melihat apakah gagasan ruang kerja bersama dapat diinjeksikan dalam ruang lingkup kantor yang konvensional dengan menggabungkan berbagai departemen maupun divisi yang dapat mengambil manfaat dari perilaku berbagi informasi.

Eksperimentasi tata ruang semacam ini juga dapat dilakukan di berbagai sekolah maupun lembaga pendidikan tinggi dengan memanfaatkan ruang-ruang yang ada seperti perpustakaan, laboratorium maupun ruang diskusi menggunakan prinsip-prinsip ruang kerja bersama sebagaimana dijelaskan dalam tulisan ini.

Penelitian-penelitian lanjutan yang dapat dikembangkan dari tulisan ini adalah penelitian lintas disiplin antar berbagai disiplin ilmu, antara lain psikologi dengan arsitektur, psikologi dengan sistem informasi juga psikologi dengan manajemen. Hal ini karena isu-isu seperti kewirausahaan, perilaku berbagai pengetahuan dan pengelolaan pengetahuan serta ruang kerja bersama bersifat multisektor.

Penelitian-penelitian tersebut dapat dilakukan demi menghasilkan pemahaman yang lebih baik tentang perilaku berbagi informasi, yang berkontribusi pada pengembangan pemahaman tentang dunia kewirausahaan kolaboratif.

\section{Ucapan Terima Kasih}

Tulisan ini merupakan bagian dari penelitian Soerjoatmodjo, G.W.L., Bagasworo, D.W., 
Joshua, G., Kalesaran, T. dan van den Broek, K. (2015) berjudul "Sharing Workspace, Sharing Knowledge: Knowledge Sharing Amongsts Entrepreneurs in Jakarta Co-Working Spaces" yang dipublikasikan dalam prosiding the $12^{\text {th }}$ International Conference in Intellectual Capital and Knowledge Management (ICICKM 2015) di Bangkok University di Thailand pada 5-6 November 2015. Penelitian ini merupakan bagian dari mata kuliah Wawancara yang dikelola oleh Program Studi Psikologi UPJ.

\section{Daftar Pustaka}

1. Bock, G.W. dan Kim, Y. (2002)

"Breaking the Myths of Rewards: An Exploratory Study of Attitudes about Knowledge Sharing" dalam Information Resources Management Journal edisi April-Juni.

2. Capdevila, I. (2013) Knowledge Dynamics in Localized Communities: Coworking Spaces as Microclusters diakses 25 Januari 2014 dari

3. http://papers.ssrn.com/sol3/papers.cfm?a bstract_id=2414121.

4. Cabrera, E.F. dan Cabrera, A. (2005) "Fostering Knowledge Sharing through People Management Practices" in The International Journal of Human Resource Management Vol. 16, Issues 5.

5. Comma (2015) "Membership Agreement" diakses 25 Mei 2015 dari http://comma.co.id/wpcontent/uploads/2014/11/MembershipAgreements.pdf

6. Duffy, F. (2000) "New Ways of Working: a Vision of the Future" in Croome, D. (editor) Creating the Productive Workplace London: Routledge.

7. Eisenmann, T.R. (2013) “Entrepreneurship: A Working Definition" dalam Harvard Business Review dipublikasikan 10 Januari 2013 dan diakses 25 Januari 2014 dari https://hbr.org/2013/01/what-isentrepreneurship

8. Fost, D. (2008) “They're Working on Their Own, Just Side by Side" dalam The New York Times dan diterbitkan tanggal 20 Februari.

9. Forlano, L. (2013) "Making Waves: Urban Technology and the CoProduction of Place" dalam First Monday, Volume 18, Number 11 - 4 November 2013 yang dapat diakses di http://www.firstmonday.dk/ojs/index.ph p/fm/article/view/4968/3797 doi: 10.5210/fm.v18i11.4968.

10. The Jakarta Globe (2013) “A Free-Form Workspace Seeks to Nurture Jakarta's Brightest" diterbitkan 4 Maret 2013 dan diakses pada 25 Mei 2015 dari http://thejakartaglobe.beritasatu.com/cou nt-me-in/a-free-form-workspace-seeksto-nurture-jakartas-brightest/ 
11. Johns, T. dan Gratton, L. (2013) "Spotlight on the Future of Knowledge Worker: The Third Wave of Virtual Work" dalam Harvard Business Review edisi Januari - Februari 2013.

12. Jones, D., Sundsted, T. \& Bacigalupo, T. (2009) I'm Outta Here! How Coworking is Making the Office Obsolete Texas: Not an MBA Press.

13. Jupp, S. (2000) New Ways of Working London: Thorogood.

14. Korunka, C. dan Gerdenitsch (2014) "New Ways of Working and Quality of Working Life: A Macroergonomic Approach" dalam Broberg, O., Fallentin, N., Hasle, P., Jensen, P.L., Kabel, A., Larsen, M.E. \& Weller, T. (editors) Human Factors in Organizational Design and Management dalam Nordic Ergonomics Society Annual Conference hal. 267-272 diakses 25 Januari 2014 dari http://proceedings.dtu.dk/fedora/reposito ry/dtu:2278/OBJ/x057.267-272.pdf.

15. Licht, A.N. dan Siegel, J.I. (2006) "The Social Dimensions of Entrepreneurship" dalam Casson, M. \& Yeung, B. (eds.) Oxford Handbook of Entrepreneurship Oxford: Oxford University Press.

16. Mardian, A. (2013) “Coworking Space Pertama di Jakarta itu Bernama Comma" dalam Inkvibe yang diakses 25 Mei 2015 dari http://inkvibe.com/2013/01/coworkingspace-bernama-comma/

17. Muhrbeck, A., Waller, R. dan Berglund, M. (2011) Coworking A Creative Workspace Thesis untuk Jönköping International Business School Bachelor Administration Jönköping University.

18. Nelson, B. (2012) “The Real Definition of Entrepreneur --- and Why It Matters" diakses 25 Januari 2015 dari http://www.forbes.com/sites/brettnelson/ 2012/06/05/the-real-definition-ofentrepreneur-and-why-it-matters/

19. O’Brien, M. (2012) “Finding a home for the 'digital nomad' " diakses 25 Januari 2015 dari situs http://www.michelleobrien.net/wpcontent/uploads/2011/10/OBRIEN_Hom e_digital_nomad.pdf

20. Orsi, J. dan Doskow, E. (2009) The Sharing Solution: How to Save Money, Simplify Your Life and Build Community California: Nolo.

21. Paulin, D. dan Suneson, K. (2012) "Knowledge Transfer, Knowledge Sharing and Knowledge Barriers - Three Blurry Terms in KM" dalam The Electronic Journal of Knowledge Management Volume 10 Issue 1 pp. 8191 tersedia di www.ejkm.com 